\title{
PEMBELAJARAN FIQIH BERBASIS MASALAH MELALUI KEGIATAN MUSYAWARAH DI PONDOK PESANTREN AL-ANWAR SARANG REMBANG
}

\author{
Fathur Rohman \\ Fathurrahman@Gmail.com \\ Universitas Islam Nahdlatul Ulama’ Jepara Jawa Tengah
}

\begin{abstract}
This article provides a description of the implementation of problem-based learning of fiqih with musyawarah activities at Pondok Pesantren Al-Anwar Sarang Rembang Central Java. The problem of this article focuses on two problems, how the implementation of problem-based learning of fiqih by musyawarah at Pondok Pesantren Al-Anwar and the advantages and disadvantages of problem based-learning of figh with musyawarah activities. This paper is the result of qualitative research using case study method. Data collection used participant observation, interview, and documentation techniques. To determine the sample of data source as informant, this research uses purposive sampling and snowball sampling technique. The data analysis technique used is descriptive qualitative analysis with phenomenology approach. The Analysis begins since the researcher goes to the place and it is done interactively and continuously until being completed. It can be concluded that the activities of musyawarah is a form of problem-based learning of fiqih in the style of pesantren. In terms of principles, characteristics, as well as learning stages in musyawarah activities have been in accordance with the concept of problem-based learning.
\end{abstract}

Key Words: Fiqih, Musyawarah, Pesantren, Problem-Based Learning

\begin{abstract}
Abstrak
Artikel ini memberikan gambaran pelaksanaan pembelajaran berbasis masalah fiqih dengan kegiatan musyawarah di Pondok Pesantren Al-Anwar Sarang Rembang Jawa Tengah. Masalah dari artikel ini berfokus pada dua masalah, bagaimana penerapan pembelajaran berbasis masalah fiqih oleh musyawarah di Pondok Pesantren Al-Anwar dan kelebihan dan kekurangan masalah berbasis-pembelajaran fiqh dengan kegiatan musyawarah. Tulisan ini merupakan hasil penelitian kualitatif dengan menggunakan metode studi kasus. Pengumpulan data menggunakan observasi partisipan, wawancara, dan teknik dokumentasi. Untuk menentukan sampel sumber data sebagai informan, penelitian ini menggunakan teknik purposive sampling dan snowball sampling. Teknik analisis data yang digunakan adalah analisis deskriptif kualitatif dengan pendekatan fenomenologi. Analisis dimulai sejak peneliti pergi ke tempat dan dilakukan secara interaktif dan terus menerus hingga selesai. Dapat disimpulkan bahwa kegiatan musyawarah merupakan bentuk pembelajaran berbasis masalah fiqih dalam gaya pesantren. Dari segi prinsip, karakteristik, serta tahapan pembelajaran dalam kegiatan musyawarah telah sesuai dengan konsep pembelajaran berbasis masalah.
\end{abstract}

Kata Kunci : Fiqih, Musyawarah, Pesantren, Problem-Based Learning. 


\section{PENDAHULUAN}

Salah satu masalah utama yang melanda dunia pendidikan islam di negeri ini adalah lemahnya proses pembelajaran. Dalam proses pendidikan, kegiatan pembelajaran merupakan kegiatan pokok dan sangat menentukan. Tercapai dan tidaknya tujuan pendidikan sangat bergantung pada bagaimana proses pembelajaran yang dijalani oleh peserta didik. Oleh karena itu, guru harus dapat memilih cara mengajar yang baik dengan menggunakan model dan pendekatan yang disesuaikan dengan kondisi dan kemampuan peserta didik (U Hasanah, 2017)

Sejauh ini proses pembelajaran di lembaga-lembaga pendidikan, terutama lembaga pendidikan islam di Indonesia dianggap oleh banyak pihak masih menggunakan sistem belajar konvensional. Dikatakan konvensional karena masih setia menggunakan cara-cara tradisional. Dalam paradigma pembelajaran konvensional anak dipandang sebagai obyek yang sifatnya pasif, pengajaran berpusat pada guru (teacher centered) dan guru adalah pemegang peranan utama dalam pembelajaran. Ivor K. Davis, sebagaimana dikutip Rusman, mengemukakan bahwa salah satu hal yang sering dilupakan adalah bahwa hakikat pembelajaran adalah bagaimana peserta didik belajar, bukan bagaimana guru mengajar. (Rusman, 2010)

Pembelajaran yang berfokus pada penguasaan materi memang terbukti berhasil dalam urusan mengingat atau memori jangka pendek, tetapi sayangnya pembelajaran macam ini gagal membekali kemampuan pemecahan masalah kepada peserta didik untuk jangka panjang. (Amri, Sofan \& Ahmadi, 2010) Jika proses pembelajaran hanya melatih peserta didik untuk menghafal atau mengerjakan tes tertulis saja, maka kemampuan peserta didik hanya terbatas pada kemampuan kognitif saja, yaitu menghafal dan mengingat. Untuk dapat menghadapi permasalahan kehidupan seharihari, peserta didik dalam proses belajarnya harus dilatih untuk terbiasa menghadapi masalah-masalah riil yang ada di sekitarnya. character building dan basic personality anak, maka harus melalui penanaman disiplin yang tinggi, agar anak memiliki kekuatan jiwa, atau mental yang tinggi, tidak mudah menyerah dengan keadaan. Dan anak dilatih untuk taat terhadap hukum yang berlaku, anak dididik mengenal reward and punishment (ganjaran dan hukuman), agar anak memiliki tanggung jawab terhadap apa saja yang ia kerjakan dan lakukan, baik dalam bentuk ucapan atau perbuatan.(Sada, 2015) 
Dalam konsep pendidikan modern, pembelajaran yang efektif adalah pembelajaran yang dapat menghadirkan kehidupan nyata ke dalam kelas dan mendorong peserta didik untuk membuat jembatan penghubung antara pengetahuan yang dimilikinya dengan penerapannya dalam kehidupan mereka sehari-hari. Dengan begitu, peserta didik akan memperoleh pengetahuan dan keterampilan dari konteks yang tidak terbatas dan setahap demi setahap dari proses mengkonstruksi pengetahuan sendiri sebagai bekal untuk memecahkan masalah dalam kehidupannya. Meminjam pandangan Popper bahwa sebenarnya belajar adalah soal pemecahan masalah, maka implikasinya, cara terbaik untuk membuat kemajuan dalam pengembangan pengetahuan adalah berfokus dalam suatu problem yang nyata, belajar memberikan solusi secara tegas dan imajinatif, dan menilai usulan solusi secara kritis (Hergenhahn \& Olson, 2009)

Bruner, senada dengan Popper menyatakan bahwa berusaha memecahkan masalah secara mandiri dengan cara eksplorasi terhadap berbagai informasi dan alternatif solusi dapat menghasilkan pengetahuan yang benar-benar bermakna. Sangat masuk akal, karena dengan berusaha mencari pemecahan masalah secara mandiri akan menghadirkan berbagai pengalaman nyata. Pengalaman-pengalaman tersebut dapat digunakan untuk memecahkan masalah jika suatu ketika peserta didik menghadapi masalah serupa, karena pengalaman itu memberikan makna tersendiri bagi peserta didik. (Trianto, 2007)

Permasalahan yang dimunculkan guru dalam pembelajaran harus kontekstual. Permasalahan yang kontekstual mendorong siswa untuk lebih aktif dan kreatif dalam memecahkan permasalahan. Permasalahan yang kontekstual membantu siswa dalam menghubungkan pengetahuan yang dipelajari di kelas dengan kondisi yang sering dihadapi di lingkungan. Penggunaan permasalahan yang kontekstual dalam pembelajaran sangat penting. Siswa terdorong untuk menghubungkan pengetahuan baru dengan pengetahuan yang telah dimiliki. Siswa juga terdorong untuk menghubungkan pengetahuan yang sudah dimiliki dengan kehidupan mereka. Penggunaan masalah yang sering dihadapi dalam kehidupan sehari-hari sebagai bahan untuk belajar dapat mendorong kemampuan siswa dalam melakukan penyelidikan. Siswa merasa lebih tertantang untuk melakukan penyelidikan jika masalah tersebut terjadi di lingkungan mereka. Pembelajaran dengan melakukan penyelidikan secara langsung di lapangan merupakan cara yang efektif untuk belajar. Problem Based Learning menekankan 
bahwa siswa berperan sebagai seorang profesional dalam menyelesaikan permasalahan yang muncul di lingkungan sekitar. Penyelesaian masalah tersebut harus didahului oleh penyelidikan yang dilakukan oleh siswa. Siswa melakukan penyelidikan mengenai masalah tersebut, misalnya penyebab masalah terjadi dan dampaknya terhadap lingkungan sekitar. Penyelidikan tersebut mengantar siswa untuk menemukan berbagai informasi mengenai masalah yang diangkat. Informasi-informasi ini membantu siswa untuk menentukan solusi yang tepat dalam memecahkan masalah tersebut. Pembelajaran seperti ini mendorong siswa untuk terampil menyelesaikan permasalahan (Maulidiyahwarti, Sumarmi, \& Amirudin, 2016)

Dalam konsep pendidikan modern, model pembelajaran yang memfokuskan pada kajian masalah-masalah faktual disebut dengan pembelajaran berbasis masalah atau Problem Based Learning. Bern dan Erickson mendefinisikan Pembelajaran Berbasis Masalah sebagai model pembelajaran yang mengajak peserta didik terlibat dalam memecahkan masalah dengan mengintegrasikan beberapa konsep dan keterampilan dari berbagai disiplin keilmuan.(Komalasari, 2010)

Pembelajaran berbasis masalah adalah salah satu model pembelajaran yang berpusat pada peserta didik (student centered) dengan cara menghadapkan peserta didik dengan berbagai masalah yang terjadi dalam kehidupan nyata. Pembelajaran difokuskan pada sebuah masalah yang harus dipecahkan oleh peserta didik, sehingga mereka merasa memiliki tanggungjawab untuk menyelesaikan masalah tersebut. Adapun guru hanya mendukung dan memberikan bimbingan kepada peserta didik (Syaifulloh, 2016)

Istilah Problem Based Learning atau Pembelajaran Berbasis Masalah (PBM), disinyalir telah dikenal semenjak era John Dewey. Pembelajaran model ini didasarkan pada kajian Dewey yang menekankan pentingnya pembelajaran melalui pengalaman. Menurut Dewey, belajar berdasarkan masalah adalah interaksi timbal balik antara stimulus dan respon yang merupakan hubungan antara dua arah, yaitu belajar dan lingkungan. Lingkungan menyajikan masalah, sedangkan pikiran berfungsi menafsirkan masalah itu, menyelidiki, menganalisis, dan mencari pemecahannya dengan baik. (Trianto, 2007)

Model pembelajaran ini mulai dipopulerkan di dunia pendidikan pada sekitar tahun 1970-an. Adalah fakultas kedokteran McMaster University di Hamilton, Ontario, Kanada, yang mulai menerapkan model ini. Berpijak pada teori Dewey, Howard S. 
Barrows, salah seorang pengajar di Universitas tersebut mencoba mengembangkan model pembelajaran yang dapat merangsang perkembangan kemampuan para calon dokter agar dapat direfleksikan dengan pengalaman dunia nyata di luar sekolah.(Amir, 2010)

Menurut Barrows, belajar dari masalah adalah cara manusia untuk tetap eksis di dunia. Dalam setiap proses penyelesaian masalah yang dihadapi, di situlah pembelajaran berlangsung. Meskipun kadang tidak menyadari hal itu, masalah merupakan proses belajar dari pengalaman yang menyediakan berbagai informasi dan pengetahuan yang bisa dijadikan bahan untuk menyelesaikan yang mungkin akan dihadapi kelak. Belajar dari masalah merupakan proses dasar pembelajaran manusia yang menjadikan manusia yang dulu primitif bisa tetap survive di lingkungannya (Barrows \& Tamblyn, 1980)

Barrows menyatakan bahwa ciri utama pembelajaran berbasis masalah yang membedakannya dengan model pembelajaran lain terletak pada penggunaan illstuctured problem sebagai sebuah stimulus dalam pembelajaran. Ill-stuctured problem adalah masalah yang kompleks yang tidak bisa dipecahkan hanya dengan pemikiran sederhana. Dalam PBM permasalahan menjadi fokus proses pembelajaran untuk menggali kemampuan pemecahan masalah (problem solving skill) dan kemampuan berpikir (reasoning skill) (Hmelo-silver \& Barrows, 2006)

Dalam konteks pembelajaran fiqih, penerapan strategi pembelajaran berbasis masalah tidak hanya menekankan pada pemahaman teoritis semata, tapi juga membantu peserta didik untuk merefleksikan pemahamannya dengan dunia nyata lewat masalahmasalah fiqhiyyah yang faktual. Seperti diketahui, fiqih merupakan ilmu yang 'amali (praktis), yang tidak bisa dilepaskan dari setiap sisi kehidupan setiap muslim. Melihat keluasan cakupan dan ruang lingkup fiqih tersebut, pastinya tidak bisa sembarangan dalam memilih dan menentukan strategi maupun metode pembelajaran. Strategi yang dipilih dalam menyajikan materi-materi fiqih haruslah benar-benar relevan sehingga tidak hanya menjamah aspek teori saja, tapi juga aspek praktis dalam kehidupan seharihari.

Berbicara tentang pembelajaran fiqih, akan menjadi dosa besar jika melupakan pesantren. Selain sebagai akar pendidikan islam di Indonesia, pendidikan pesantren yang berlabel salaf memang lebih cenderung bercorak fiqih. Baik secara kualitas maupun kuantitas, pembahasan fiqih masih sangat mendominasi di atas bidang-bidang 
ilmu lain. Meskipun, semua pesantren tentu saja mengajarkan ilmu alat, tafsir, tauhid, dan ilmu-ilmu lain, namun inti pendidikan pesantren salf sebenarnya terdiri dari karyakarya fiqih (Bruinessen, 1999)

Salah satu pesantren yang dikenal luas di kawasan Jawa Tengah sebagai pesantren berbasis Fiqih adalah pondok pesantren Al-Anwar Sarang Rembang. Dalam pembelajaran fiqih, Pesantren asuhan KH. Maimoen Zubair ini selain menggunakan model-model pembelajaran klasik seperti bandongan, hafalan, dan sorogan sebagai metode utama, juga menggunakan model pembelajaran berbasis masalah. Model pembelajaran berbasis masalah diimplementasikan melalui kegiatan musyawarah yang diselenggarakan setiap hari. Kegiatan ini merupakan forum bagi santri untuk mengkaji berbagai masalah fiqhiyyah waqi'iyyah haditsah atau masalah fiqih faktual kontemporer.

Salah satu kajian tentang pembelajaran fiqih berbasis masalah pernah dilakukan oleh Sufinatin Aisida dengan tajuk "Aplikasi Model Problem Based Learning sebagai Motivasi dalam Pembelajaran Fiqih". Artikel konsepsional ini mengkaji kelebihan model Problem Based Learning dalam menumbuhkan motivasi belajar peserta didik terhadap ilmu fiqih. Menurutnya, masalah yang disajikan dalam PBL dapat menjadi pelecut motivasi belajar fiqih pada peserta didik (Aisida, 2017). Ahmad Syaifulloh juga pernah melakukan penelitian tentang pembelajaran berbasis masalah dengan judul "Pengaruh Strategi Problem-Based Learning (PBL) terhadap Motivasi dan Hasil Belajar Peserta Didik pada Mata Pelajaran Fiqih di MA Khozinatul ‘Ulum Blora Jawa Tengah”. Artikel ini merupakan hasil penelitian kuantitatif dengan metode eksperimen. Desain yang digunakan adalah True Experimental Design dengan bentuk Pretest-Posttest Control Group Design. Hasil penelitian ini menunjukkan bahwa Strategi ProblemBased Learning berpengaruh terhadap motivasi dan hasil belajar peserta didik dalam mata pelajaran Fiqih (Syaifulloh, 2016). Penelitian serupa juga pernah dilakukan oleh M. Mujahidin dalam tesisnya yang berjudul "Implementasi Metode Pembelajaran Berbasis Masalah (Problem Based Learning) pada Mata Pelajaran Fiqih Kelas VIII di Madrasah Tsanawiyah Muhajirin Surabaya". Penelitian ini merupakan penelitian kualitatif dengan metode studi kasus. Hasil penelitian ini menunjukkan bahwa penerapan PBL di Madrasah Tsanawiyah Muhajirin Surabaya sangat membantu guru 
dalam mengelola kelas dan membangkitkan motivasi peserta didik dalam mata pelajaran fiqih

Berdasarkan penelitian terdahulu, telah dilakukan penelitian dalam mengkaji pembelajaran fiqh (Uswatun Hasanah, 2016; Mukhoyyaroh \& Jazil, 2013; Saleh, 2013) dan pembelajaran berbasis masalah sendiri sebenarnya telah banyak dikaji dan diteliti dalam pembelajaran (Ainin, 2017; Ghofuri, Sanusi, \& Krisdiana, 2014; Maulidiyahwarti et al., 2016; Mustofa, Susilo, \& Muhdhar, 2016; Pranawestu, Kharis, \& Mariani, 2012; Saleh, 2013; Widodo, 2016; Yustianingsih, Syarifuddin, \& Yerizon, 2017), baik pada bidang fiqih maupun PAI secara umum, serta kegiatan musyawarah banyak dilakukan dalam pembelajaran (Hariyanto, 2014; Nurhayati, 2014) namun penelitian dengan obyek pesantren masih belum banyak.

Berdasarkan uraian tersebut, penelitian ini dimaksudkan untuk mendeskripsikan proses pembelajaran fiqih berbasis masalah melalui kegiatan musyawarah di Pondok Pesantren Al-Anwar Sarang Rembang. Adapun rumusan masalah dalam penelitian ini difokuskan pada pertanyaan bagaimana pembelajaran fiqih berbasis masalah melalui kegiatan musyawarah di Pondok Pesantren Al-Anwar Sarang Rembang, dan apa kelebihan serta kekurangannya. Hasil penelitian ini diharapkan menjadi sebuah tawaran model pembelajaran bagi lembaga pendidikan islam formal dalam rangka pengembangan pembelajaran mata pelajaran PAI, khususnya fiqih.

\section{METODE PENELITIAN}

Penelitian ini termasuk kategori penelitian deskriptif-kualitatif karena untuk menemukan data yang dibutuhkan perlu terlibat langsung dalam latar belakang masalah serta orang-orang tertentu yang diteliti. Adapun metode yang digunakan adalah studi kasus yaitu metode atau strategi penelitian dan sekaligus hasil penelitian pada kasus tertentu. Penelitian studi kasus ditujukan untuk mengumpulkan data, mengambil makna, dan memperoleh pemahaman dari kasus tersebut.(Sukmadinata, 2009) Sumadi Suryabarata mengemukakan bahwa tujuan penelitian kasus adalah untuk mempelajari latar belakang keadaan dan interaksi lingkungan suatu unit sosial baik individu, kelompok, lembaga, atau masyarakat secara intensif.(Suryabrata, 1995)

Sumber data dalam penelitian ini diklasifikasikan menjadi tiga. Pertama, person atau individu yang diteliti dan segala aktivitasnya. Dalam hal ini person adalah 
pengasuh, para ustadz, dan santri Pesantren Al-Anwar. Kedua, place atau tempat yang menjadi lokasi penelitian dengan segala isinya. Place adalah Pondok Pesantren AlAnwar dengan segala yang ditampilkan baik diam maupun gerak. Ketiga, paper atau dokumen, yaitu segala dokumen baik fisik maupun virtual yang berkaitan dengan Pembelajaran fiqih di PP. Al-Anwar. Untuk menentukan sampel sumber data sebagai informan, teknik yang digunakan adalah purposive sampling dan dengan teknik snowball sampling. Artinya, penentuan sampel sumber data bersifat fleksibel dan bisa berkembang setelah peneliti turun gunung. Namun, untuk mengawali penggalian data di lapangan, sampel sumber data hendaknya dipilih dari kalangan yang memiliki otoritas sehingga akan memudahkan peneliti dalam mengumpulkan data.

Untuk mengumpulkan data-data tersebut, peneliti menggunakan metode partisipant observation dengan cara terlibat langsung dalam kegiatan musyawarah di PP. Al-Anwar Sarang Rembang untuk memperoleh informasi secara komprehensif, bahkan yang paling kecil sekalipun. Selain observasi, wawancara juga dibutuhkan oleh peneliti untuk menggali data yang mungkin belum bisa didapatkan pada observasi. Wawancara difokuskan pada pengasuh, ustadz pembimbing kegiatan musyawarah, dan santri yang mengikuti kegiatan musyawarah. Dokumentasi juga dilakukan untuk menggali data-data tentang pesantren seperti profil, keadaan guru, peserta didik, maupun jadwal kegiatan pesantren. Untuk menguji validitas dan kredibilitas data, peneliti melakukan pengecekan terhadap seluruh data yang diperoleh apakah benar atau tidak, berubah atau tidak. Jika data yang diperoleh sudah benar, maka data dianggap kredibel, tetapi jika tidak, maka peneliti perlu melakukan observasi lanjutan. Pengecekan ulang juga dilakukan terhadap hasil wawancara dengan cara membaca ulang hasil wawancara. Jika memang telah sesuai tujuan, maka tidak perlu melakukan wawancara kembali. Tetapi jika dirasa kurang atau belum sesuai dengan tujuan penelitian, maka peneliti perlu melakukan wawancara kembali.

Adapun teknik analisis yang digunakan adalah analisis deskriptif kualitatif. Dalam studi kasus, analisis data dilakukan semenjak peneliti terjun ke lapangan dan dilakukan secara terus menerus. Analisis data dalam studi kasus juga tidak kaku, tetapi luwes dan dapat berkembang sesuai perkembangan lapangan. Miles dan Huberman mengemukakan bahwa analisis data dalam penelitian kualitatif dilakukan secara interaktif dan terus menerus hingga tuntas, sehingga datanya sudah jenuh. Adapun 
langkah-langkahnya adalah redukti data yaitu merangkum dan memilah data-data pokok. Lalu dilanjutkan dengan penyajian data dan diakhiri dengan penarikan kesimpulan dan verifikasi. (Sugiyono, 2009)

\section{HASIL PENELITIAN DAN PEMBAHASAN}

\section{Al-Anwar; Pesantren dengan Corak Fiqih}

Pondok Pesantren Al-Anwar, yang lebih terkenal dengan sebutan Pondok Sarang, adalah satu pondok pesantren tradisional yang cukup masyhur di kalangan masyarakat Jawa. Pondok ini terletak di daerah pesisir laut Jawa, tepatnya di Desa Karangmangu Kecamatan Sarang Kabupaten Rembang Jawa Tengah. Secara geografis, Pondok Pesantren Al-Anwar berbatasan dengan laut Jawa di sebelah utara, dengan Jalur Pantura di sebelah selatan, desa Tempeyak di sebelah timur, dan Desa Bajingjawa di sebelah barat.

Pesantren Al-Anwar didirikan pada tahun 1967 oleh KH. Maimoen Zubair atau lebih akrab disapa Mbah Maimoen, salah satu Mustasyar PBNU dan juga Kiai sepuh yang sangat berpengaruh di Indonesia. Mulanya, pesantren ini adalah sebuah majlis ta'lim milik ayahanda Mbah Moen, yaitu KH. Zubair Dahlan. Sepulangnya dari studi di Mekkah, Maimoen muda diberikan kepercayaan untuk menggantikan peran ayahnya memimpin Majlis Ta'lim. Semakin banyaknya santri yang ingin ngaji di sana, maka dengan bangunan seadanya mushalla tempat majlis ta'lim dijadikan pesantren dengan nama POHAMA atau Pondok Haji Maimoen. Selang beberapa tahun, nama POHAMA dirubah menjadi Al-Anwar untuk mengenang ayah beliau yang sebelum menunaikan ibadah haji bernama Anwar.

Semenjak berganti nama itu, jumlah santri pondok Al-Anwar semakin meningkat pesat. Sampai saat ini, PP. Al-Anwar telah mengalami kemajuan yang sangat signifikan dan telah menjelma menjadi salah satu pesantren besar di Jawa yang menjadi rujukan dalam ilmu fiqih. Selain faktor kharisma sang Kyai sebagai salah satu Kyai nasional, kemajuan Al-Anwar juga ditunjang oleh konsistensi keilmuan dan sistem pendidikan yang diterapkan. Di atas lahan $7.712 \mathrm{~m}^{2}$ Al-Anwar menampung santri mukim lebih dari 2000 orang, putra maupun putri yang kesemuanya berasal dari berbagai penjuru di Indonesia. PP Al-Anwar juga telah memiliki lembaga pendidikan formal yaitu MI, MTs, dan MA Al-Anwar. Bahkan saat ini, Al-Anwar telah memiliki 
perguruan tinggi, yaitu Sekolah Tinggi Agama Islam Al-Anwar yang didirikan pada tahun 2011.

Pondok pesantren Al-Anwar merupakan salah satu contoh pesantren salaf dengan corak fiqhi. Hal ini bisa dilihat, salah satunya dari kurikulum pesantren yang didominasi kitab-kitab fiqih. Pada kegiatan pengajian rutin, materi fiqih menduduki peringkat paling tinggi dengan 6 kitab, disusul Nahwu dengan 5 kitab, tasawuf dengan 4 kitab, hadits 2 kitab, dan masing-masing 1 kitab untuk materi Tafsir, Ushul Fiqih, Manthiq, Balaghah, Tajwid, dan Faraidl. Demikian pula pada kurikulum madrasah diniyyah Muhadlarah pesantren. Materi fiqih menjadi materi wajib di setiap marhalah (kelas), mulai dari marhalah I'dadiyyah (persiapan) hingga marhalah VI dan Ma'had Aly.

Secara umum, baik ditinjau dari kurikulum madrasah Muhadlarah maupun pengajian umum harian, kitab fiqih juga lebih mendominasi hingga $11.8 \%$ daripada kitab lain. 85 Kitab dari 21 bidang ilmu yang diajarkan, 10 di antaranya merupakan kitab fiqih dan sisanya merupakan kitab-kitab lain. Adapun perinciannya adalah sebagai berikut.

Tabel 1

Bidang Kitab yang diajarkan di PP. Al-Anwar

\begin{tabular}{|c|l|c|c|}
\hline No & \multicolumn{1}{|c|}{ Mata Pelajaran } & $\begin{array}{c}\text { Jumlah Kitab } \\
\text { yang dikaji }\end{array}$ & Persentase \\
\hline 1 & Tauhid & 8 & 9.4 \\
\hline 2 & Fiqih & 10 & 11.8 \\
\hline 3 & Nahwu & 8 & 9.4 \\
\hline 4 & Sharf & 3 & 3.5 \\
\hline 5 & Akhlaq & 4 & 4.7 \\
\hline 6 & I'rab & 4 & 4.7 \\
\hline 7 & Tajwid & 4 & 4.7 \\
\hline 8 & I'lal & 2 & 8.2 \\
\hline 9 & Hadits & 7 & 3.5 \\
\hline 10 & Fara'idl & 3 & 5.9 \\
\hline 11 & Tarikh & 4 & 4.7 \\
\hline 12 & Ushul Fiqh & & \\
\hline
\end{tabular}




\begin{tabular}{|c|l|c|c|}
\hline 13 & Qawa'id Fiqhiyyah & 3 & 3.5 \\
\hline 14 & Ilmu Hadits & 3 & 3.5 \\
\hline 15 & Tafsir & 2 & 2.4 \\
\hline 16 & Ilmu Manthiq & 2 & 2.4 \\
\hline 17 & Balaghah & 3 & 3.5 \\
\hline 18 & Ilmu al-Qur'an & 3 & 3.5 \\
\hline 19 & Tashawwuf & 5 & 5.9 \\
\hline 20 & Ilmu 'Arudl & 1 & 1.2 \\
\hline 21 & Ilmu Falak & 1 & 1.2 \\
\hline \multicolumn{2}{|c|}{ Jumlah } & 85 & 100 \\
\hline
\end{tabular}

Selain faktor kurikulum di atas, corak fiqih Pondok pesantren Al-anwar juga ditunjukkan dalam kegiatan pembelajaran. Selain diajarkan dengan model klasikal di kelas madrasah Muhadlarah dan secara umum lewat pengajian rutin, materi fiqih juga menjadi materi wajib kegiatan muhafadzah dan musyawarah. Matan Taqrib merupakan salah satu materi yang wajib dihafalkan santri di pendidikan Muhadlarah, selain materi tata bahasa Arab dan Tauhid. Fiqih juga menjadi materi khusus untuk kegiatan Musyawarah untuk marhalah V sampai dengan Ma'had 'Aly dengan kitab Fath alQarib, Fath al-Mu'in, dan Syarh al-Mahally. Pengkhususan ini kecuali dimaksudkan untuk mengkonsentrasikan pendidikan santri pada ilmu Fiqih, juga bertujuan untuk mengasah kemampuan analisis santri dalam bidang hukum islam.

\section{Pembelajaran Fiqih Berbasis Masalah dengan Model Musyawarah}

Secara teoritis, pesantren sebagai sebuah lembaga tradisional bisa jadi belum mengenal atau mengetahui model pembelajaran berbasis masalah. Tetapi secara praktis, sebenarnya mereka telah menerapkan pembelajaran berbasis masalah meskipun tidak sesempurna konsepnya. Adalah kegiatan musyawarah yang merupakan wujud pembelajaran berbasis masalah ala pesantren. Kegiatan tersebut merupakan tradisi intelektual di pesantren salaf yang masih dilestarikan hingga saat ini. Dalam kegiatan itu, santri dibimbing ustadz membahas berbagai permasalahan faktual sesuai materi pembelajaran. Tujuannya untuk melatih para santri dalam memecahkan masalah dengan menggunakan pola berpikir dan argumentasi yang lurus. Materi yang bersumber dari 
kitab kuning diimprovisasi dengan pendekatan kontekstual melalui kajian-kajian terhadap masalah-masalah faktual sehingga santri memiliki daya kritis dan tradisi penalaran yang baik.(Sulaiman, 2010)

Tentang term musyawarah sendiri, dalam literatur kepesantrenan juga sering disebut dengan istilah bahts al-masa'il. Dua term ini secara terminologis memang sama, namun dalam aplikasinya terdapat sedikit perbedaan. Dalam musyawarah, pembahasan masalah masih terbingkai dalam kurikulum yang berlaku di pesantren, sedangkan dalam bahts al-masa'il, masalah yang dikaji tidak terikat dengan suatu tema tertentu, tetapi bisa dari berbagai tema fiqih. Bahts al-masa'il biasanya dilaksanakan secara non klasikal dan formal sedangkan musyawarah dilaksanakan dengan sistem klassikal. Namun demikian, tujuan dari kedua kegiatan ini kurang lebih sama, yakni membahas masalah-masalah fiqih.

Tradisi musyawarah atau bahts al-masa'il mempunyai kaitan erat dengan Nahdlatul Ulama'. Hal ini dapat dilihat dari fakta bahwasanya NU juga mempunyai sebuah institusi yang bernama Lajnah Bahtsul Masa'il. Lajnah ini merupakan forum resmi yang memiliki otoritas menjawab segala permasalahan keagamaan yang dihadapi masyarakat. Data-data yang menginformasikan kelahiran dan perkembangan Lajnah Bahtsul Masa'il ini baik dari sisi latar belakang, metode, obyek, maupun sejarahnya masih sangat sedikit. Namun, bila dilihat dari latar belakang berdirinya NU, kemunculan Lajnah Bahtsul Masa'il merupakan jawaban atas kebutuhan masyarakat terhadap hukum islam yang praktis bagi kehidupan sehari-hari. Bila ditelusuri ke belakang, bisa diketahui bahwa bahts al-masa'il pertama kali dilaksanakan pada tahun 1926, beberapa bulan setelah berdirinya NU(Zahro, 2004)

Keterkaitan metode musyawarah atau bahts al-masa'il dengan Nahdlatul Ulama' juga diperkuat dengan fakta bahwa kebanyakan pesantren yang menerapkan metode seperti ini adalah pesantren salaf yang notabene berafiliasi pada Nahdlatul Ulama'. Pesantren-pesantren modern yang muncul belakangan sangat jarang yang menggunakan metode seperti ini. Hal ini sangat mungkin karena sumber utama dalam metode bahts al-masa'il adalah kitab-kitab salaf, sedangkan pesantren modern yang ada sekarang ini lebih mengutamakan pendidikan modern daripada menekuni kitab-kitab kuning. 
Di pondok pesantren Al-Anwar, pembelajaran fiqih berbasis masalah diimplementasikan melalui kegiatan musyawarah fiqhiyyah yang dilaksanakan setiap hari kecuali hari Selasa dan Jumat. Musyawarah fiqhiyyah merupakan salah satu program unggulan PP. Al-Anwar dan mendapat porsi paling banyak dibanding kegiatan lain. Kegiatan musyawarah fiqhiyyah ini hanya dikhususkan bagi santri marhalah V, VI madrasah Muhadlarah dan santri Ma'had 'Aly. Pertimbangannya, selain telah digembleng hafalan matan taqrib di Marhalah I dan II, santri kelas V ke atas dipandang telah mempunyai bekal pemahaman fiqih yang cukup, baik secara hukmi ataupun manhaji sehingga santri tidak akan kesulitan dalam mengikuti proses analisis masalah dan hukum-hukum terkait. Adapun marhalah IV ke bawah juga melaksanakan kegiatan musyawarah, tetapi dengan materi yang akan dipelajari esok di madrasah Muhadlarah.

Adapun materi pembelajaran dalam kegiatan musyawarah disesuaikan dengan kelas di madrasah Muhadlarah . Untuk marhalah V dan VI, kajiannya adalah kitab Fath al-Qarib, sedangkan untuk santri Ma'had Aly menggunakan kitab Fath al-Mu'in dan al-Mahally. Masing-masing kelas mushawarah ini dikoordinir oleh seorang koordinator dan sekretaris. Koordinator kelas ini bertanggung jawab atas jadwalisasi Qari' (presenter) dan moderator musyawarah untuk tiap pertemuan. Bersama sekretaris, koordinator juga bertanggung jawab atas presensi peserta musyawarah untuk tiap pertemuannya. Sedangkan sekretaris bertugas mencatat jadwalisasi, presensi santri dan masalah-masalah yang dibahas dalam forum musyawarah beserta solusinya.

Selain musyawarah fiqih harian, PP. Al-Anwar juga menyelenggarakan musyawarah fiqih bulanan dan musyawarah tahunan atau biasa disebut dengan musyawarah kubra. Musyawarah fiqih bulanan sebenarnya diselenggarakan setiap tiga minggu sekali tetapi seringkali disebut bulanan karena lebih mudah penyebutannya. Sedangkan musyawarah kubra adalah musyawarah yang dilaksanakan setahun sekali dalam rangka memperingati milad PP. Al-Anwar dengan melibatkan delegasi dari pesantren lain. Pembelajaran fiqih dengan kegiatan musyawarah ini, selain bertujuan untuk meningkatkan pemahaman santri terhadap materi pelajaran, juga untuk mengembangkan kemampuan analisis hukum islam dan memecahkan masalah-masalah fiqih yang muncul di masyarakat. Dengan adanya masalah yang harus dipecahkan oleh santri, mereka akan belajar secara mandiri untuk mencari informasi dari kitab-kitab fiqih yang lebih luas, menganalisa, dan menyimpulkan hasil analisa tersebut. 
Adapun proses pembelajaran dalam kegiatan musyawarah menjadi tanggung jawab penuh santri peserta musyawarah. Kegiatan dipimpin oleh seorang pimpinan musyawarah dan seorang notulis dari kalangan peserta musyawarah sendiri sesuai giliran yang telah ditetapkan oleh koordinator musyawarah. Pemberian tanggungjawab penuh kepada santri ini dilakukan untuk membiasakan santri belajar secara mandiri sekaligus melatih santri menjadi pemimpin agar kelak siap ketika harus terjun ke masyarakat. Sementara ustadz hanya bertugas membimbing, mengawasi, dan mengevaluasi di akhir kegiatan. Ustadz tidak turut campur dalam proses pembelajaran, karena urusan pengelolaan forum dan penyampaian materi sudah dilimpahkan kepada pimpinan musyawarah dan Qari'. Ustadz hanya akan melakukan intervensi jika dipandang perlu atau diminta oleh musyawirin. Namun demikian, kehadiran ustadz, yang hanya sebatas mengawasi ini secara tidak langsung merupakan sebuah motivasi dan kontrol bagi santri dalam pembelajaran karena merasa diawasi oleh ustadz.

Proses pembelajaran dalam kegiatan musyawarah secara umum terdiri dari beberapa tahap. Pertama, pembukaan musyawarah oleh pimpinan musyawarah dilanjutkan penyampaian tema dan bahan pelajaran yang akan dibahas. Materi pembelajaran dipresentasikan oleh santri yang bertugas sesuai jadwal dengan membaca teks kitab fiqih kemudian menterjemahkannya dan menjelaskan kandungan kitab tersebut. Kedua, setelah pemaparan materi, pimpinan musyawarah membuka waktu untuk sesi tanya jawab seputar teks kitab dan maknanya selama 30 menit. Selanjutnya, pimpinan musyawarah membuka sesi waqi'iyyah, yakni sesi pembahasan masalahmasalah fiqih faktual dan kontemporer. Sesi ini diberikan porsi waktu 1 jam dan terkadang bisa lebih melihat masalah yang sedang dipecahkan. Adapun tahapan dalam sesi waqi'iyyah antara lain :

a. Pengajuan masalah. Pada tahap ini, peserta musyawarah diberikan waktu untuk mengajukan problem, masalah, atau kasus fiqhiyyah yang berkaitan dengan materi pembahasan. Masalah biasanya dideskripsikan dalam bentuk narasi sebuah fenomena yang mengandung kesenjangan dalam hukum islam. Permasalahan yang diangkat dalam sesi ini harus memenuhi ketentuan yaitu faktual, kontemporer, belum pernah dibahas sebelumnya, dan sesuai dengan tema yang dibahas. 
b. Seleksi masalah. Pada tahap ini, pimpinan musyawarah menampung masalah yang diajukan oleh peserta kemudian menawarkan masalah kepada para peserta untuk diseleksi dengan cara diskusi dan kemudian disetujui untuk dibahas. Dalam musyawarah harian, masalah yang dibahas dibatasi hanya satu masalah karena waktunya yang relatif sedikit.

c. Tashawwur al-Mas'alah atau pendefinisian masalah. Yaitu tahap pendalaman deskripsi masalah, analisis masalah, pembahasan istilah-istilah terkait masalah, dan klarifikasi kepada sa'il atau yang mengajukan masalah.

d. Ketika permasalahan dianggap cukup jelas, maka para santri diberikan waktu untuk melakukan pencarian informasi, data, dan solusi terkait permasalahan yang dikaji melalui kitab-kitab fiqih. Pencarian tersebut dilakukan secara berkelompok kemudian didiskusikan dengan anggota kelompok masing-masing. Temuan-temuan di tingkat kelompok tersebut kemudian diajukan sebagai alternatif solusi kepada pimpinan musyawarah untuk kemudian dikomunikasikan dengan semua peserta musyawarah .

e. al-Radd wa al-I'tiradl. Secara bahasa berarti bantahan dan sanggahan. Pada tahap ini santri menganalisis berbagai alternatif solusi yang telah diajukan masing-masing kelompok dan mendiskusikannya untuk menentukan solusi yang paling relevan. Tahap ini biasanya memakan waktu yang cukup lama karena terjadi adu data dan argumen dari tiap-tiap kelompok yang mengajukan jawaban.

f. Menentukan solusi. Setelah mendiskusikan beberapa alternatif, maka ditentukan solusi yang paling relevan yang kemudian dirumuskan menjadi kesepakatan forum. Namun apabila tidak terjadi kesepakatan atau tidak ditemukan pemecahan masalah, maka masalah akan di-mauquf-kan atau ditangguhkan. Masalah yang ditangguhkan ini selanjutnya akan dibawa kepada forum musyawarah bulanan.

Ketiga, Setelah proses pembahasan masalah beserta solusinya usai, selanjutnya dilakukan evaluasi dari ustadz. Dalam hal ini, ustadz memberikan pengarahan dan koreksi tentang kinerja santri dalam proses musyawarah beserta produk hukum yang dihasilkan. 
Adapun musyawarah bulanan atau sering disebut dengan bahts mauqufah adalah tindak lanjut dari musyawarah harian. Kegiatan ini merupakan forum untuk mengkaji dan memecahkan berbagai masalah yang mauquf atau ditangguhkan di musyawarah harian. Semua masalah yang ditangguhkan di semua kelas musyawarah, selanjutnya diajukan kepada Tim mauqufah pada masing-masing tingkat. Di tim mauqufah ini, masalah-masalah yang ditangguhkan ditampung dan diseleksi untuk diangkat ke dalam forum musyawarah bulanan. Sebelum pelaksanaan kegiatan ini, tim mauqufah biasanya memberikan edaran berisi daftar masalah yang akan dibahas kepada tiap-tiap kelas agar dipelajari dan dikerjakan secara kelompok.

Ditinjau dari proses pembelajaran, tahapan dalam kegiatan musyawarah bulanan baik harian, bulanan, atau tahunan adalah sama. Perbedannya hanya terletak pada materi pembelajaran. Dalam musyawarah harian, kegiatan selalu diawali dengan penyampaian materi dari kitab kuning yang dikaji, sementara pada musyawarah bulanan dan tahunan, pembahasan langsung menukik pada masalah, tanpa diawali penyampaian materi dari kitab kuning. Sementara secara konten, musyawarah bulanan dan tahunan lebih luas dan kaya daripada musyawarah harian karena masalah yang diangkat merupakan kumpulan dari materi yang permasalahan yang tidak terselesaikan di musyawarah harian. Pembahasannya lebih terperinci karena waktu yang diberikan cukup panjang dan pesertanya juga terdiri dari berbagai kelas musyawarah.

\section{Kelebihan dan Kekurangan Musyawarah}

Tidak ada model pembelajaran yang sempurna. Setiap model pembelajaran tentu mengandung kelebihan dan kekurangan. Model pembelajaran berbasis masalah sebagaimana dipraktekkan oleh Pondok Pesantren Al-Anwar melalui kegiatan musyawarah mempunyai beberapa keunggulan. Pertama, keunggulan terletak pada masalah yang dijadikan fokus pembelajaran. Melalui masalah yang dikaji, model musyawarah dapat menantang santri untuk aktif berpikir dan belajar mandiri (self directed). Santri tidak hanya belajar untuk mengetahui, tapi lewat proses pemecahan masalah, mereka juga belajar untuk belajar (learning to learn). Kecuali itu, pemecahan masalah juga akan menantang kemampuan santri, jika mereka berhasil memecahkannya maka itu akan memberikan kepuasan tersendiri. 
Kedua, Pembelajaran yang didesain dengan menugaskan santri untuk berperan sebagaimana peran guru, yakni sebagai pimpinan musyawarah dan presentator dapat memberikan pembelajaran kepada santri tentang bagaimana berhadapan dengan masyarakat, memfasilitasi dan mengelola forum untuk skala yang lebih besar, yakni di kehidupan nyata kelak. Dengan desain seperti ini, tanpa adanya ustadz dalam forum proses pembelajaran akan tetap berjalan. Ketiga, peran ustadz yang terbatas hanya mengawasi dan mengevaluasi pembelajaran, memberikan peluang bagi santri untuk lebih bebas dan terbuka dalam mengembangkan pembelajaran secara mandiri. Santri tidak perlu merasa malu atau canggung mengutarakan pikiran dan pendapat karena ustadz tidak akan mengintervensi jalannya proses musyawarah.

Keempat, pembelajaran fiqih berbasis masalah dengan kegiatan musyawarah merupakan wujud pembelajaran dengan prinsip berkesinambungan dan tuntas. Pembelajaran dilaksanakan setiap hari dan apabila pembelajaran pemecahan masalah telah mentok di musyawarah harian, penyelesaian masalah masih ditindaklanjuti dalam forum musyawarah bulanan hingga permasalahan benar-benar tuntas.

Kelima, kegiatan musyawarah mengajarkan dan membiasakan santri untuk saling menghargai dan menghormati perbedaan pendapat. Dalam kajian fiqih, perbedaan adalah hal yang lumrah, baik dalam satu ataupun lintas madzhab. Dengan sering berkomunikasi, bertukar pikiran, dan berdiskusi dengan berbagai pandangan yang berbeda akan membuka wawasan santri sehingga tidak merasa paling benar sendiri dan mampu menerima perbedaan.

Di samping beberapa kelebihan di atas, ada beberapa kekurangan yang dapat dicermati dari desain pembelajaran dengan model musyawarah. Pertama, kegiatan musyawarah membutuhkan persiapan yang cukup. Kurangnya persiapan akan mengakibatkan kesulitan dalam mengikuti pembelajaran, karena di forum ini santri harus belajar, bereksplorasi, dan mengembangkan pengetahuan secara mandiri. Dengan berjalannya pembelajaran setiap hari, santri yang sulit mengikuti pelajaran akan semakin jauh tertinggal. Kondisi ini lama kelamaan akan menimbulkan kebosanan dan kejenuhan bagi santri karena harus mengejar banyak ketertinggalan.

Kedua, memberikan peran kepada santri menjadi pimpinan musyawarah, satu sisi merupakan kelebihan, tapi juga memunculkan kelemahan di sisi lain. Hal itu memungkinkan peserta kurang menghargai kepemimpinan temannya sesama santri, 
apalagi jika pimpinan musyawarah kurang cakap mengelola forum, sehingga forum tidak kondusif, pembahasan terlalu bebas dan kurang terarah. Ketiga, proses pembelajaran berbasis masalah membutuhkan waktu yang cukup lama, sehingga alokasi waktu yang sedikit akan mempengaruhi efektifitas pembelajaran. Dalam musyawarah harian, dengan alokasi waktu 2 jam yang dibagi menjadi dua sessi, yakni pembahasan teks kitab dan waqi'iyyah, tentunya proses pembelajaran dengan pemecahan masalah fiqih tidak bisa sepenuhnya efektif. Maka terkadang santri dengan inisiatif sendiri menambah waktu kegiatan musyawarah hingga tengah malam.

Beberapa kelamahan-kelamahan di atas, sejauh pengamatan penulis bukanlah kelemahan subtansial yang sangat menghambat jalannya proses pembelajaran. Terlepas dari kelemahan-kelemahan itu pembelajaran fiqih berbasis masalah dengan kegiatan musyawarah dapat dikatakan berjalan sesuai dengan prinsip-prinsip pembelajaran berbasis masalah.

\section{SIMPULAN DAN SARAN}

Pondok pesantren Al-Anwar merupakan salah satu contoh pesantren salaf dengan corak fiqhi. Hal ini bisa dilihat dari kurikulum pesantren yang memang didominasi kitab-kitab fiqih. Kecenderungan fiqih pesantren ini juga ditunjukkan dengan adanya kegiatan musyawarah fiqhiyyah yang dilaksanakan setiap hari. Kegiatan musyawarah selain bertujuan untuk meningkatkan pemahaman santri terhadap ilmu fiqih, juga untuk mengembangkan kemampuan analisis hukum islam dan memecahkan masalah-masalah fiqih yang muncul di masyarakat. Dengan adanya masalah yang harus dipecahkan oleh santri, mereka akan belajar secara mandiri untuk mencari informasi dari kitab-kitab fiqih, menganalisa, dan menyimpulkan hasil analisa tersebut. Kegaitan musyawarah ini secara prinsip merupakan implementasi dari pembelajaran berbasis masalah dalam bidang fiqih. Meskipun tidak sesempurna konsep aslinya, model musyawarah telah memenuhi prinsip dan karakteristik pembelajaran berbasis masalah. Maka, tidak terlalu berlebihan jika dikatakan bahwa musyawarah merupakan model pembelajaran fiqih berbasis masalah ala pesantren. Model pembelajaran musyawarah merupakan salah satu tradisi intelektual pesantren yang telah berjalan setua umur pesantren itu sendiri. Meskipun berlabel lembaga pendidikan tradisional, ternyata 
pesantren telah melangkah di depan lembaga pendidikan modern dalam penerapan model pembelajaran berbasis masalah. 


\section{DAFTAR PUSTAKA}

Ainin, M. (2017). Efektifitas Penggunaan Pendekatan Pembelajaran Berbasis Masalah (Problem Based Learning) Dalam Pembelajaran Matakuliahmetodologi Penelitian Bahasa Arab. Bahasa Dan Seni, 45(2), 197-207.

Aisida, S. (2017). Aplikasi Model Problem Based Learning sebagai Motivasi dalam Pembelajaran Fiqih. An-Nuha, 4(1), 18-39.

Amir, M. T. (2010). Inovasi Pendidikan Melalui Problem Based Learning. Jakarta: Kencana Prenada Media Group.

Amri, Sofan \& Ahmadi, I. K. (2010). Proses Pembelajaran Innovatif dan Kreatif dalam Kelas. Jakarta: Prestasi Pustakaraya.

Barrows, H. S., \& Tamblyn, R. M. (1980). Problem-Based Learning, an Approach to Medical Education. New York: Springer Publishing Compan.

Bruinessen, M. Van. (1999). Kitab Kuning, Pesantren dan Tarekat. Bandung: Mizan.

Ghofuri, A. M., Sanusi, \& Krisdiana, I. (2014). Efektivitas Pembelajaran Berbasis Multimedia Menggunakan Power Point Dengan Pendekatan Pembelajaran Berbasis Masalah (Problem Based Learning) Ditinjau Dari Motivasi Belajar Siswa. JIPM : Jurnal Ilmiah Pendidikan Matematika, 3(1), 1-7.

Hariyanto. (2014). Prinsip Keadilan dan Musyawarah Dalam Hukum Islam Serta Implementasinya Dalam Negara Hukum Indonesia. Justitia Islamica, 11(1), 44-66.

Hasanah, U. (2016). Penerapan Strategi Pembelajaran Mind Mapping Untuk Meningkatkan Hasil Belajar Peserta Didik Pada Mata Pelajaran Fiqih Kelas VII A MTS Nurul Islam Air Bakoman Kabupaten Tanggamus. Al-Idarah: Jurnal Kependidikan Islam, 6(2), 41-60.

Hasanah, U. (2017). Peningkatan Hasil Belajar Mata Pelajaran Fiqih melalui Penerapan Metode PQRST (Preview, Question, Read, Summarize, Test) Peserta Didik Kelas V di MI Ismaria al-Qur'aniyah Islamiyah Raja Basa Bandar Lampung Tahun Pelajaran 2016/2017. Al-Tadzkiyyah: Jurnal Pendidikan Islam, 8(1), 1-14.

Hergenhahn, B., \& Olson, M. H. (2009). Theories of Learning terj. Tri Wibowo BS. Jakarta: Kencana Prenada Media Group.

Hmelo-silver, C. E., \& Barrows, H. S. (2006). Goals and Strategies of a Problem-based Learning Facilitator. Interdisciplinary Journal of Problem-Based Learning, 1(1), $5-22$.

Komalasari, K. (2010). Pembelajaran Kontekstual: Konsep dan Aplikasi. Bandung: Refika Aditama.

Maulidiyahwarti, G., Sumarmi, \& Amirudin, A. (2016). Pengaruh Model Problem Based Learning Berbasis Outdoor Study Terhadap Hasil Belajar Siswa Kelas XI IIS SMA. Jurnal Pendidikan: Teori, Penelitian, Dan Pengembangan, 1(2), 94100. 
Mukhoyyaroh, S., \& Jazil, S. (2013). Pengaruh Model Pembelajaran Kooperatif Tipe TPS ( Think Pair Share ) Terhadap Pemahaman Siswa Pada Mata Pelajaran Fiqih Kelas VII MTS Al-Irsyadiyah Dermolemahbang Sarirejo Lamongan. Jurnal Pendidikan Agama Islam, 1(1), 23-44.

Mustofa, Z., Susilo, H., \& Muhdhar, M. H. I. Al. (2016). Penerapan Model Pembelajaran Problem Based Learning Melalui Pendekatan Kontekstual Berbasis Lesson Study Untuk Meningkatkan Kemampuan Memecahkan Masalah Dan Hasil Belajar Kognitif Siswa SMA. Jurnal Pendidikan: Teori, Penelitian, Dan Pengembangan, 1(5), 885-889.

Nurhayati, S. F. (2014). Engelolaan Pasar Tradisional Berbasis Musyawarah Untuk Mufakat. Benefit : Jurnal Manajemen Dan Bisnis, 18(1), 49-56.

Pranawestu, A., Kharis, M., \& Mariani, S. (2012). Keefektifan Problem Based Learning Berbantuan CABRI 3D Berbasis Karakter Terhadap Kemampuan Spasial. Unnes Journal of Mathematics Education, 1(2), 1-6.

Rusman. (2010). Model-Model Pembelajaran. Jakarta: Raja Grafindo Persada.

Sada, H. J. (2015). Konsep Pembentukan Kepribadian Anak Dalam Perspektif AlQur'an (Surat Luqman Ayat 12-19). Al-Tadzkiyyah: Jurnal Pendidikan Islam, 6(2), 253-272.

Saleh, M. (2013). Strategi Pembelajaran Fiqh Dengan Problem Based Learning. Jurnal Ilmiah DIDAKTIKA, XIV(1), 190-220.

Sugiyono. (2009). Metode Penelitian Kuantitatif, Kualitatif, dan $R \&$ D. Bandung: Alfabeta.

Sukmadinata, N. S. (2009). Metode Penelitian Pendidikan. Bandung: Remaja Rosdakarya.

Sulaiman, I. (2010). Masa Depan Pesantren: Eksistensi Pesantren di Tengah Gelombang Modernisasi. Malang: Madani.

Suryabrata, S. (1995). Metodologi Penelitian. Jakarta: Raja Grafindo Persada.

Syaifulloh, A. (2016). Pengaruh Strategi Problem-Based Learning (PBL) terhadap Motivasi dan Hasil Belajar Peserta Didik pada Mata Pelajaran Fiqih di MA Khozinatul 'Ulum Blora Jawa Tengah. Wahana Akademika, 3(2), 121-136.

Trianto. (2007). Model-model Pembelajaran Inovatif Berorientasi Konstruktivistik: Konsep, Landasan Teoritis-Praktis dan Implementasinya. Jakarta: Prestasi Pustakaraya.

Widodo, S. (2016). Pengembangan Keterampilan Berpikir Kritis Peserta Didik Dengan Menggunakan Model Pembelajaran Berbasis Masalah (Problem Based Learning) Melalui Isu-Isu Sosial Ekonomi Pasca Penggenangan Waduk Jatigede Dalam Pembelajaran IPS di SMPN 2 Wado Kabupaten Sumeda. International Journal Pedagogy of Social Studies, 1(2), 1-14. 
Yustianingsih, R., Syarifuddin, H., \& Yerizon. (2017). Pengembangan Perangkat Pembelajaran Matematika Berbasis Problem Based Learning (Pbl) Untuk Meningkatkan Kemampuan Pemecahan Masalah Peserta Didik Kelas VII. Jurnal JNPM ( Jurnal Nasional Pendidikan Matematika ), 1(2), 258-274.

Zahro, A. (2004). Tradisi Intelektual NU. Yogyakarta: LKiS. 